\title{
RODITELJSKI SAVEZ I NJEGOVE RELACIJE SA KOMPONENTAMA PSIHOFIZIČKOG ZDRAVLJA DETETA
}

\author{
Đerđi Erdeš - Kavečan ${ }^{1}$ \\ Departman za psihologiju, Univerzitet u Novom Pazaru
}

U istraživačkoj literaturi roditeljski savez se najčešće navodi kao konceptualni termin koji se odnosi na način na koji se roditelji ili roditeljske figure obraćaju jedno drugom u ulozi roditelja. Koroditeljstvo se javlja kada se preklapaju ili dele odgovornosti pojedinaca u odgajanju dece, a sastoji se od podrške $i$ koordinacije (ili nedostatka iste) koje roditeljske figure primenjuju na deci. Roditeljski savez ne uključuje romantične, seksualne, emotivne, finansijske i zakonske veze medu partnerima i ne podrazumeva egalitarnost $u$ roditeljskim ulogama.

Istraživanje je sprovedeno sa ciljem da se ispitaju relacije između roditeljskog saveza $i$ komponenata psihofizičkog zdravlja deteta predškolskog $i$ osnovnoškolskog uzrasta. Uzorak istraživanja su činile majke (248) sa teritorije Novog Sada. Podatke smo sakupili pomoću dva instrumenta, Skale za procenu Snage Roditeljskog Saveza (Abidin, Konold, 1999) i Upitnika za ispitivanje Zdravlja Dece (sastavljen za potrebe istraživanja od 40 ajtema obuhvaćenih u okviru 8 subskala koje mere psihosocijalno i fizičko zdravlje iz CHQ/Child Health Questionnaire, Landgraf, Ware Jr.,1996).

Analizom latentnog prostora istraživanja došli smo do podataka, da je roditeljski savez povezan sa čak pet dimenzija psihosocijalnog i jednom dimenzijom fizičkog zdravlja deteta. Ovi podaci nam svakako sugerišu značajnost roditeljskih $i$ uopšteno porodičnih odnosa u generisanju zdravog emocionalnog, socijalnog i fizičkog funkcionisanja deteta. Ipak, pojedine uzroke lošijeg psihofizičkog funkcionisanja individue je teško otkriti. $U$ tom svetlu, preciznije informacije bi se mogle dobiti ispitivanjem ličnih

\footnotetext{
${ }^{1}$ E-mail: djerdji.kavecan@gmail.com
} 
karakteristika kako roditelja, tako i dece, kao i ispitivanjem konteksta u kom se roditeljstvo odvija.

Ključne reči: roditeljski savez, psihofizičko zdravlje, relacije, metrijske karakteristike

\section{Uvod}

Mnogobrojna istraživanja su pokazala, da su bračni i partnerski odnosi asocirani sa roditeljstvom i prilagođavanjem dece. Na osnovu sve obimnije literature iz oblasti porodične psihologije, uvaženi naučnici su još pre 20 godina zaključili, da su najbolji prediktori dečijih problema neadekvatni bračni odnosi (Emery, 1982. Hetherington, Cox \& Cox, 1982.).

Eksplicitan pojam o koroditeljstvu (roditeljska saradnja) pojavio se iz dva izvora: pripadnici sistemske porodične teorije su je opisali, kao izvršni sistem, koji se sastoji od roditelja i njihovih uloga kao ko-upravljača ponašanja članova porodice i njihovih odnosa u cilju regulisanja porodičnih interakcija (Framo, 1972; P. Minuchin, 1985; S. Minuchin, 1974). Sa druge strane, teoretičari objektnih odnosa Vajsman i Koen (Weissman, Cohen, 1985) su opisali roditeljsku saradnju iliti roditeljski savez kao priznavanje i odavanje poštovanja roditeljskoj kompetenciji partnera, koju on demonstrira u stresnim i kontinuirano napetim situacijama u mnogobrojnim oblastima roditeljstva. Po mišljenju ovih autora, takva vrsta odnosa u velikoj meri utiče na roditeljsko samopoštovanje.

Margolin i saradnici (2001) smatraju da težak ili neadekvatan roditeljski odnos može predstavljati rizični mehanizam, koji povezuje kvalitet relacije između roditelja i uspešnost porodice kao celine, iako teškoća u opštim odnosima između roditelja može biti samo marker ili indikator rizika (Rutter, 1994). Nekolicina istraživanja sprovedena u poslednjoj deceniji na nerazvedenim, dvoroditeljskim porodicama je potvrdila činjenicu, da roditeljski odnos ima jači uticaj na samo roditeljstvo i prilagođavanje deteta nego bilo koji drugi aspekti odnosa među partnerima (Abidin \& Bruner, 1995; Feinberg et al., 2003).

Veliki broj autora roditeljsku saradnju posmatra kroz model, koji obuhvata četiri komponente. Ove četiri komponente su sledeće: dogovori oko pitanja vezanih za odgajanje dece, podela poslova u kući i oko dece, podrška uloge drugog roditelja i zajedničko rukovođenje porodičnim interakcijama. 


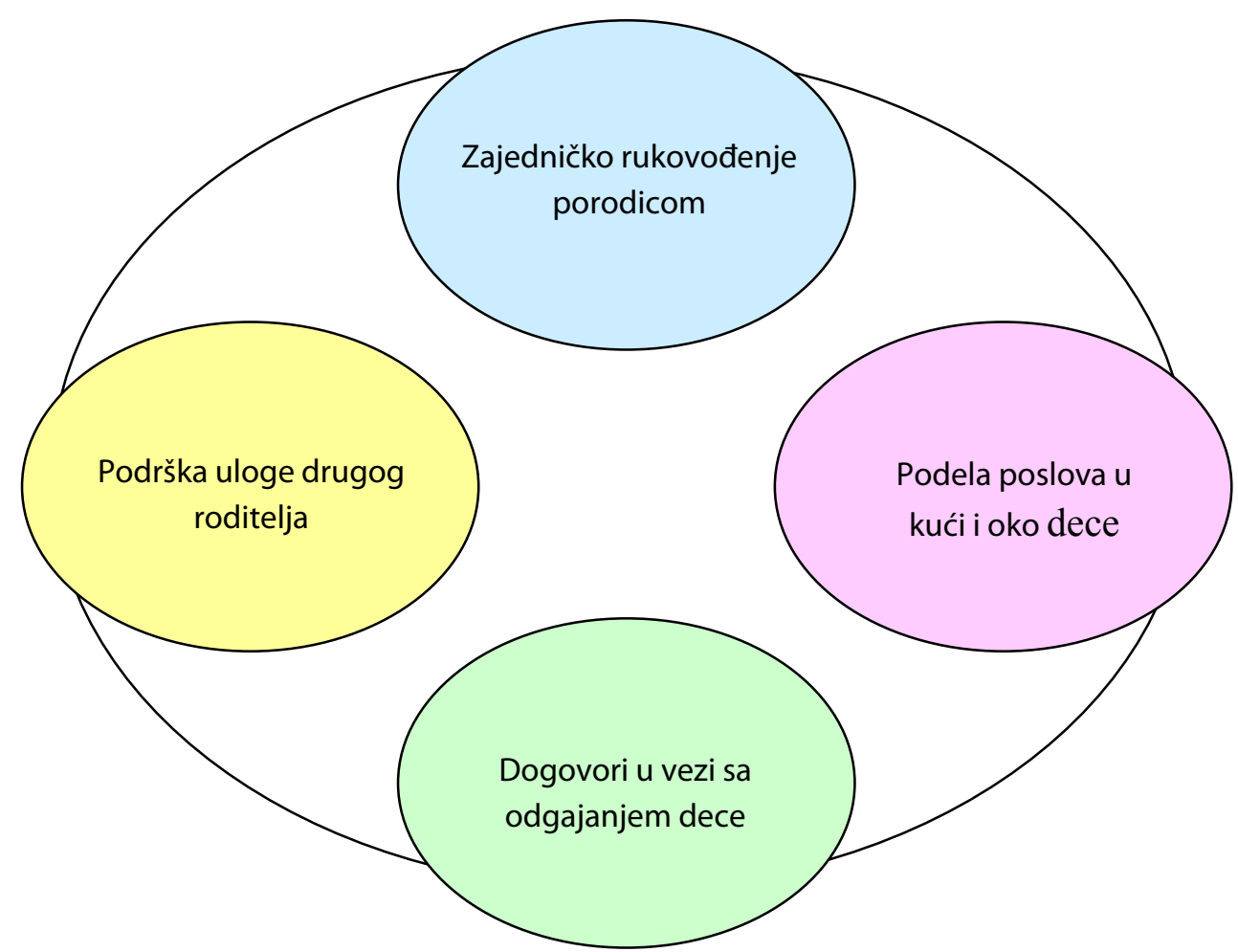

Slika 1. Model komponenti roditeljskog saveza (Izvor: Unutrašnja struktura i ekološki kontekst roditeljskog saveza (Feinberg, 2003))

Stepen povezanosti među prethodno navedenim komponentama u svakoj porodici je različit. Na primer, neki roditelji koji se ne slažu oko pitanja vezanih za odgajanje dece, mogu da ponude jedno drugom roditeljsku podršku, da efikasno pregovaraju oko odgovornosti, i/ili da nastave sa konfliktnim odnosima, ali pri tom da vode računa o tome, da deca ne budu izložena preteranom neprijateljstvu. Sa druge strane, drugi roditelji koji se slažu oko vaspitnih postupaka, mogu da ispolje veoma štetne obrasce ponašanja u drugim sferama roditeljstva (Mcbride \& Rane, 1998).

Razmatrajući relacije spomenutih komponenata roditeljskog saveza i opšteg psihofizičkog blagostanja deteta, utvrđeno je, da je neslaganje roditelja oko vaspitnih postupaka najviše povezano sa bihejvioralnim problemima dece u predškolskom periodu, (Block, Block \& Morrison, 1981; Deal et al., 1989), kao i tokom perioda adolescencije (Feinberg et al., 2003). Takođe se pokazalo, da ista varijabla visoko korelira sa moralnim rasuđivanjem dečaka, njihovom druželjubivošću, kao i sa emocionalnim distanciranjem. Kod devojčica, nesla- 
ganje oko vaspitnih postupaka asocirano je sa samopoštovanjem, osećanjem odgovornosti, socijalnim veštinama i sposobnošću da se suoče sa problemima i slobodnim izražavanjem (Vaughn, Block \& Block, 1988.) među partnerima (Abidin \& Bruner, 1995; Feinberg et al., 2003). Podrška uloge drugog roditelja kao posebna komponenta roditeljskog saveza takođe je asocirana sa prilagođavanjem roditelja i deteta, sa percepcijom roditeljske kompetencije, kao i sa problemima u ponašanju dece i adolescenata (Floyd \& Zmich, 1991).

Ipak, većina istraživača roditeljski savez procenjuje kao jednodimenzionalni konstrukt, koji je značajan u predikciji kvaliteta roditeljstva. Vajsman i Koen (Weissman, Cohen, 1985) smatraju, da ukoliko roditelji imaju snažan roditeljski savez, biće sposobni zajednički da vaspitavaju svoju decu i u veoma stresnim situacijama, pa čak i nakon raspada porodičnog sistema.

Rukovodeći se rezultatima dosadašnjih studija iz oblasti roditeljstva, koji ukazuju na značajan uticaj odnosa među partnerima na ponašanje dece (Erel, Burnman, 1995., Repetti, 1989.), ovim istraživanjem smo želeli da ispitamo da li i u kolikoj meri kvalitet koroditeljske saradnje ima efekta na psihosocijalno i fizičko blagostanje dece predškolskog i školskog uzrasta.

\section{Metod}

\section{Uzorak}

Ovaj rad je deo šire empirijske studije koja je imala za cilj da ispita psihofizičko zdravlje deteta i karakteristike porodičnih odnosa u strukturalno različitim porodicama. Istraživanjem je obuhvaćeno 248 roditelja dece predškolskog i školskog uzrasta sa teritorije Novog Sada. Od ukupnog broja ispitanih roditelja 176 (71 \%) je bilo iz potpunih, dok je $72(29 \%)$ iz jednoroditeljskih porodica. Uzorak istraživanja su činile isključivo majke.

\section{Instrumenti}

Kvalitet roditeljske saradnje meren je Skalom za procenu Snage Roditeljskog Saveza / Parenting Alliance Measure (Abidin, Konold, 1999.). Upitnik se sastoji od 20 tvrdnji, koje se odnose na različite oblike saradnje roditelja, kako bi izašli u susret potrebama deteta. Roditelji dece do adolescentnog uzrasta na petostepenoj skali procenjuju koliko je za njih karakterističan sadržaj određene tvrdnje. 
Validacione studije govore o zadovoljavajućim metrijskim karakteristikama ovog instrumenta. Kronbahov alfa koeficijent iznosi .95, a test-retest provera .80. Dokazana je i tendencija stabilnosti tokom vremena (Abidin, Konold, 1999).

U ovom istraživanju psihometrijske karakteristike, veličina unutrašnje konzistentnosti $(\alpha=.96)$ i korelacija ajtema sa prvom glavnom komponentom $(\beta$ $=.97$ ), dozvoljavaju nam da je tretiramo kao jedinstvenu meru snage roditeljskog saveza i to u obliku prve glavne komponente. Viši skor na Skali ukazuje na slabiju koroditeljsku saradnju. Detaljnjiji podaci o metrijskim karakteristikama i faktorskoj strukturi Skale PAM, prikazani su u Magistarskoj tezi Erdeš-Kavečan (2009).

Za procenu psihosocijalnog i fizičkog blagostanja dece, u istraživanju je korišćena modifikovana verzija Upitnika za ispitivanje Zdravlja dece / Child Health Questionnaire (Landgraf, Ware Jr., 1996). Originalan Upitnik sastoji se od 14 subskala i meri dimenzije (komponente) Globalnog psihosocijalnog i Globalnog fizičkog zdravlja deteta, dok se u našem istraživanju dimenzije procenjuju kroz 7 preuzetih subskala iz originalnog CHQ Upitnika, koje su sledeće: ostvarivanje socijalne uloge (zavisno od emocionalnog stanja), samoprocena/samopoštovanje, mentalno zdravlje i generalno ponašanje (Globalno Psihosocijalno zdravlje), zatim, generalno zdravlje, telesna bol i promene u zdravlju (Globalno Fizičko zdravlje). Izbor subskala u našem istraživanju za merenje Psihosocijalnog i Fizičkog zdravlja deteta bio je uslovljen ciljevima i zadacima šire empirijske studije, te su odnosi u okviru porodice, kao što je uticaj na roditelje ili porodične aktivnosti i povezanost članova porodice (subskale u originalnoj verziji CHQ Upitnika) ispitivani drugim relevantnim instrumentima: FACES III - Skala za ispitivanje porodične kohezivnosti i adaptibilnosti (Olson et al., 1985) i MCRE - Upitnik za Evaluaciju Odnosa Majka - Dete (Roth, 1961).

Za merenje psihičkog i fizičkog blagostanja dece korišteno je sledećih 12 dimenzija: Samopoštovanje, Mentalno zdravlje, Ostvarivanje socijalne uloge zavisno od emocionalnog stanja, Problemi u ponašanju i poteškoće vezane za učenje, Prisustvo zdravstvenih problema koji su psihogenog karaktera, Prisustvo hroničnih zdravstvenih problema, Generalno zdravlje i učestalost simptoma, Problemi vezani za socijalno funkcionisanje deteta, Dijabetes, Promene u zdravlju, Opšte blagostanje $i$ Zdravstveni problemi vezani za vid deteta. Viši skorovi na svim subskalama govore o odsustvu simptoma i boljem zdravlju deteta.

Pouzdanost instrumenta je u prihvatljivim granicama, sa Kronbahovim alfa koeficijentima koji se kreću od .63 do .85. Niža pouzdanost (.57) nađena je za 
subskalu, koju smo nazvali Prisustvo zdravstvenih problema, a kada je u pitanju procena generalnog zdravlja, učestalosti telesne boli, kao i promene $u$ zdravlju, takođe su dobijeni niži koeficijenti pouzdanosti (od .30 do .41), međutim treba da uzmemo u obzir, da je ovakva pouzdanost svakako određena malim brojem ajtema koji ih predstavljaju, a da skromnu interkorelaciju varijabli (od .11 do .21) možemo objasniti heterogenošću posmatranih dimenzija fizičkog zdravlja deteta. Detaljnija analiza metrijskih karakteristika, kao i faktorska struktura ovako modifikovanog instrumenta, prikazana je u Magistarskoj tezi Erdeš-Kavečan (2009).

\section{Rezultati}

Deskriptivni pokazatelji kvaliteta funkcionisanja roditeljskog saveza i psihofizičkog zdravlja deteta u našem uzorku

Tabela 1. Prikaz kvaliteta roditeljske saradnje u ispitivanim porodicama

\begin{tabular}{llc}
\hline Kvalitet roditeljske saradnje & AS & SD \\
\hline Jednoroditeljske porodice & 62.44 & 13.31 \\
Dvoroditeljske porodice & 35.76 & 22.31 \\
\hline
\end{tabular}

Rezultati pokazuju, da su prosečne vrednosti izrazito veće u jednoroditeljskim porodicama, te možemo da konstatujemo, da su samohrani roditelji mnogo nezadovoljniji saradnjom sa drugim roditeljem i da veći procenat samohranih roditelja ne dobija adekvatnu pomoć od bivšeg supružnika kada je u pitanju zadovoljenje detetovih svakodnevnih potreba. Statističkom analizom potvrđena je i značajnost razlike među posmatranim grupama $(t=-9.480, \mathrm{p}<.01)$.

Tabela 2 Prikaz psihosocijalnog zdravlja deteta u ispitivanim porodicama

\begin{tabular}{llll}
\hline Psihosocijalno zdravlje & Porodična struktura & AS & SD \\
\hline Ostvarivanje soc. uloge & Jednoroditeljske porodice & 10.19 & 1.83 \\
zavisno od emoc. stanja & Dvoroditeljske porodice & 11.26 & 1.42 \\
\cline { 2 - 4 } Problemi u ponašanju & Jednoroditeljske porodice & 18.76 & 2.32 \\
\cline { 2 - 4 } & Dvoroditeljske porodice & 21.04 & 2.84 \\
\hline
\end{tabular}




\begin{tabular}{llcc}
\hline Mentalno zdravlje & Jednoroditeljske porodice & 17.71 & 2.52 \\
& Dvoroditeljske porodice & 19.64 & 2.61 \\
Samopoštovanje & Jednoroditeljske porodice & 23.01 & 4.39 \\
& Dvoroditeljske porodice & 25.44 & 3.56 \\
\hline
\end{tabular}

Upoređujući prosečne vrednosti u jednoroditeljskim i dvoroditeljskim porodicama, možemo da konstatujemo, da se u porodičnim sistemima sa jednim roditeljem na svim dimenzijama psihosocijalnog zdravlja registruju manje vrednosti, što nas upoznaje sa činjenicom, da samohrani roditelji psihosocijalno blagostanje svoje dece procenjuju kao znatno lošije. Signifikantne razlike se pokazuju u svim dimenzijama psihosocijalnog zdravlja i to za ostvarivanje socijalne uloge zavisno od emocionalnog stanja $(\mathrm{t}=4.434, \mathrm{p}=.000)$, ponašanje deteta $(\mathrm{t}=6.031, \mathrm{p}=.000)$, mentalno zdravlje $(\mathrm{t}=5.335, \mathrm{p}=.000)$, kao i za dimenziju samopoštovanje $(\mathrm{t}=4.535, \mathrm{p}=.000)$.

Tabela 3. Prikaz fizičkog zdravlja deteta u ispitivanim porodicama

\begin{tabular}{llll}
\hline Fizičko zdravlje & Porodična struktura & AS & SD \\
\hline Generalno zdravlje & Jednoroditeljske porodice & 4.31 & .94 \\
& Dvoroditeljske porodice & 4.40 & .75 \\
Učestalost telesne boli & Jednoroditeljske porodice & 5.00 & .82 \\
& Dvoroditeljske porodice & 5.29 & .816 \\
Promene u zdravlju & Jednoroditeljske porodice & 3.57 & .85 \\
& Dvoroditeljske porodice & 3.64 & .86 \\
Prisustvo zdravstvenih & Jednoroditeljske porodice & 33.99 & 1.77 \\
problema & Dvoroditeljske porodice & 35.02 & 1.34 \\
\hline
\end{tabular}

Prosečni skorovi u tabeli 3 nam pokazuju, da su vrednosti u svim posmatranim dimenzijama zdravlja veći u dvoroditeljskim porodicama. Ipak, statistički značajna razlika je utvrđena za samo dve dimenzije fizičkog zdravlja, a to su: prisustvo hroničnih zdravstvenih problema $(\mathrm{t}=5.006, \mathrm{p}<.01)$ i učestalost telesne boli $(\mathrm{t}=2.582, \mathrm{p}<.05)$. Za dimenzije generalno zdravlje $(\mathrm{t}=.813, \mathrm{p}=$ 
$.417)$ i promene u zdravlju $(\mathrm{t}=.603, \mathrm{p}=.547)$ statistički značajne razlike nisu registrovane.

Povezanost kvaliteta roditeljske saradnje i dimenzija psihofizičkog zdravlja deteta

Kako bi se ispitale i opisale relacije između kvaliteta koroditeljske saradnje i psihofizičkog zdravlja deteta, izračunate su korelacije na Promax - faktorima, koji su dobijeni analizom strukture Upitnika CHQ i prvoj glavnoj komponenti Skale PAM. U tabeli 4 vidljivi su koeficijenti, koji ukazuju na značajnu povezanost čak šest dimenzija zdravlja sa kvalitetom roditeljske saradnje.

Tabela 4. Korelacije među faktorima psihofizičkog zdravlja deteta (CHQ) i kvaliteta roditeljske saradnje (PAM) na celokupnom uzorku

\begin{tabular}{ll}
\hline Psihofizičko zdravlje deteta & Kvalitet roditeljske saradnje \\
\hline Samopoštovanje & $-.267^{*}$ \\
Mentalno zdravlje & $-.385^{*}$ \\
Ostvarivanje soc.uloge zavisno od emoc.stanja & $-.361^{*}$ \\
Problemi u ponašanju i poteškoće u učenju & $-.205^{*}$ \\
Prisustvo zdravstvenih problema koji su psihogenog & -.005 \\
karaktera & \\
Prisustvo hroničnih zdravstvenih problema & $-.240^{*}$ \\
Generalno zdravlje i učestalost simptoma & -.192 \\
Problemi vezani za soc. funkcionisanje & -.028 \\
Dijabetes & -.044 \\
Promene u zdravlju & -.116 \\
Opšte blagostanje & $-.232^{*}$ \\
Zdravstveni problemi vezani za vid & -.025 \\
\hline * $<$.01 &
\end{tabular}

$* \mathrm{p}<.01$

Psihofizičko zdravlje (CHQ) - niži skor, lošije zdravlje, prisustvo simptoma 
Kvalitet roditeljske saradnje (PAM) - niži skor, kvalitetnija saradnja među roditeljima

Kada pogledamo rezultate u prethodnoj tabeli, možemo da uočimo da je snaga roditeljskog saveza povezana sa pet dimenzija psihosocijalnog (mentalno zdravlje, ostvarivanje socijalne uloge zavisno od emocionalnog stanja, samopoštovanje, opšte blagostanje i problemi u ponašanju i poteškoće u učenju) i sa jednom dimenzijom fizičkog zdravlja deteta (prisustvo hroničnih zdravstvenih problema), što nam svakako govori o tome, da je roditeljska saradnja povezana sa skoro svim merenim dimenzijama psihosocijalnog zdravlja deteta.

Kako bismo imali uvid u celinu ispitivanog problema, u narednoj tabeli prikazani su međusobni odnosi posmatrane dve varijable u okviru poduzoraka samohranih majki i majki iz dvoroditeljskih porodica.

Tabela 5. Korelacije medu faktorima psihofizičkog zdravlja deteta (CHQ) i kvaliteta roditeljske saradnje (PAM) u jednoroditeljskim $i$ dvoroditeljskim porodicama

\begin{tabular}{lll}
\hline Psihofizičko zdravlje deteta & \multicolumn{2}{l}{ Kvalitet roditeljske saradnje } \\
\cline { 2 - 3 } & $\begin{array}{l}\text { Jednorodit. } \\
\text { porodice }\end{array}$ & $\begin{array}{l}\text { Dvorodit. po- } \\
\text { rodice }\end{array}$ \\
\hline Samopoštovanje & $-\mathbf{2 1 0 *}$ & -.123 \\
Mentalno zdravlje & -.177 & $-.248^{*}$ \\
Ostvarivanje soc.uloge zavisno od emoc.stanja & $-.428^{*}$ & -.133 \\
Problemi u ponašanju i poteškoće u učenju & -.110 & -.103 \\
Prisustvo zdravstvenih problema koji su psihogenog & -.088 & .114 \\
karaktera & & -.119 \\
Prisustvo hroničnih zdravstvenih problema & -.040 & $-.233^{*}$ \\
Generalno zdravlje i učestalost simptoma & -.069 & .023 \\
Problemi vezani za soc. funkcionisanje & -.049 & .141 \\
Dijabetes & -.127 & -.116 \\
Promene u zdravlju & -.070 & \\
\hline
\end{tabular}


Opšte blagostanje

Zdravstveni problemi vezani za vid
$-.276 *$

$-.120$
$-.148$

$-.031$

$*_{p}<.01$

- Psihofizičko zdravlje (CHQ) - niži skor, lošije zdravlje, prisustvo simptoma

- Kvalitet roditeljske saradnje (PAM) - niži skor, kvalitetnija saradnja među roditeljima

Podaci u tabeli 5 nam pokazuju, da roditeljska saradnja nije povezana sa istim dimenzijama psihofizičkog zdravlja deteta u strukturalno različitim porodicama. Naime, u jednoroditeljskim porodičnim sistemima značajna korelacija je uočena između roditeljske saradnje sa jedne strane i samopoštovanja, ostvarivanja socijalne uloge koja je zavisna od emocionalnog stanja i opšteg blagostanja sa druge strane, dok se u potpunim porodicama značajna povezanost registruje između koroditeljske saradnje i mentalnog zdravlja, kao i koroditeljske saradnje i generalnog zdravlja deteta.

\section{Diskusija i zaključak}

Poznato je, da je uloga porodice odlučujuća u razvoju, kao i da su atmosfera i odnosi unutar nje presudni u životu svakog pojedinca. Usklađenost odnosa između članova porodice i emocionalna povezanost dece sa roditeljima značajno doprinose porodičnom skladu i stabilnosti, koje su osnova za zdrav psihički i fizički razvoj dece. Kako emotivnu klimu u porodici kreiraju roditelji, njihova uloga u podizanju i vaspitanju dece je nezamenljiva. Ipak, danas je neodrživ model jednosmernog uticaja roditelja na dete, jer dete svojim karakteristikama i vrednostima bitno utiče na roditeljevo ponašanje, te shodno koncepcijama sistemske porodične teorije, razmena među članovima porodice je kauzalna i ciklična.

Mnogobrojna relevantna istraživanja nam pokazuju, da neadekvatna saradnja među roditeljima, slaba socijalna podrška, kao i loša ekonomska situacija ne predstavljaju rizične faktore samo za zdravlje deteta, već nepovoljno utiču i na delotvorno vaspitanje deteta, jer doprinose pojavi depresivnosti kod roditelja. Depresivnost skreće pažnju roditelja sa potrebe deteta i povećava tendenciju da dečijem ponašanju neproporcionalno pridaje negativno tumačenje i povezana je sa više odbacivanja, kritičnosti i negativnih emocija prema detetu. Vaspitanje je kod takvih roditelja najčešće nedosledno, što svakako doprinosi i niskom samopoštovanju deteta i čest je slučaj da dete doživljava neuspeh u 
školi (problem sa postignućem) ili ima velike teškoće u prilagođavanju, kao i probleme u ponašanju (Berg - Nielsen i sar., 2002). Istraživanja Amata i Belskog (Amato, 1998. Belsky et al. 1991) takođe govore o tome, da su neadekvatni odnosi roditelja asocirani sa problemima u ponašanju dece, sa niskim samopoštovanjem, sa poteškoćama u prilagođavanju, lošijim dostignućima u obrazovanju i slabijim održavanjem veza sa rođacima.

Prema Koulmanovom (Coleman, 1988, 1990) shvatanju o društvenom kapitalu porodice, ističe se posebna važnost roditelja kao resursa za svoju decu. Po tome, društveni porodični kapital leži u snazi veze između roditelja i dece i ima značajne posledice po razvoj dece. Taj nalaz je potkrepljen i istraživanjima, koji pozitivne odnose između roditelja i dece povezuje sa psihofizičkim blagostanjem dece (Belsky, Putnam \& Crnic, 1996).

U skladu sa spomenutim svetskim istraživanjima, rezultati našeg istraživanja pokazuju, da je roditeljski savez povezan sa skoro svim merenim dimenzijama psihosocijalnog zdravlja (mentalno zdravlje, samopoštovanje, ostvarivanje socijalne uloge zavisno od emocionalnog stanja, problemi u ponašanju i učenju, opšte blagostanje) i sa jednom dimenzijom fizičkog zdravlja deteta (prisustvo hroničnih zdravstvenih problema), pri čemu je slabija roditeljska saradnja asocirana sa lošijim psihosocijalnim zdravljem i prisustvom većeg broja hroničnih zdravstvenih problema kod deteta, te prethodne analize koje govore o nedostatku roditeljske saradnje i lošijem zdravlju dece u jednoroditeljskim porodicama samo potkrepljuju ovaj nalaz. Međutim, povezanost koja je uočena između koroditeljske saradnje i prisustva hroničnih zdravstvenih tegoba podstiče nas na razmišljanje, jer po nekim autorima neadekvatna saradnja roditelja još ne predstavlja razlog za hronično oboljevanje deteta, ali može da bude efekat lošijih uslova života i smanjenog kapaciteta roditelja da vodi računa o zdravlju svog deteta (Conger et al., 1994). Sa druge strane, uočena povezanost bi mogla takođe da ukazuje na pogoršanje odnosa među roditeljima usled kumulativnog stresa, koji je izazvan hroničnom bolešću ili fizičkom osetljivošću deteta. Kako u ovom istraživanju smer povezanosti među posmatranim varijablama nismo ispitali, ukazuje se potreba da se u narednim istraživanjima posebno posvetimo ovom pitanju.

S obzirom da smo u našem istraživanju utvrdili da deca iz nepotpunih porodica imaju generalno lošije psihosocijalno i fizičko zdravlje od dece iz porodica sa oba prisutna roditelja, rezultati se svakako slažu sa podacima, koji su dobili Anthony (1974) i Hetherington (1979), koji su ponašanje dece iz samohranih porodica okarakterisali kao „razdražljivo“ i "nesigurno“. Takvo ponašanje je po njima povezano sa načinom na koji se roditelji ponašaju, njihovim kvalitetom međusobnog odnosa i usklađenošću postupaka prema svom detetu. 
Naši podaci takođe govore o tome, da koroditeljska saradnja nije povezana sa istim dimenzijama zdravlja u porodičnim sistemima sa jednim ili oba roditelja. U nepotpunim porodicama slabija saradnja roditelja je asocirana sa nižim samopoštovanjem deteta, kao i sa poteškoćama u ostvarivanju socijalnih kontakata usled emotivnih problema. Objašnjenje za spomenute poteškoće stručnjaci nalaze u Bolbijevoj teoriji afektivnog vezivanja (Bowlby, 1969; Kennedy \& Kennedy, 2004), po kojoj gubitak jednog roditelja za koga je dete bilo vezano izaziva strepnju kod deteta i ispoljava se u vidu uznemirenosti i nedostatka poverenja u sopstvene mogućnosti. Kada su potpune porodice u pitanju, naši rezultati ukazuju na povezanost između slabije roditeljska saradnje i česte fluktuacije raspoloženja i lošijeg generalnog zdravlja deteta. Moguće je da je ovakva razlika u povezanosti koroditeljske saradnje i komponenata zdravlja $\mathrm{u}$ potpunim i nepotpunim porodicama pored već spomenutih različitih spoljašnjih uslova života određena i stepenom uključenosti oca u brigu deteta, jer je poznato da svakodnevna uključenost oca u proces vaspitanja i socijalizacije deteta uvećava mogućnost zbližavanja i produbljivanja emotivnih veza među članovima porodice (psihološka i interaktivna dimenzija) i doprinosi opštem blagostanju deteta. S obzirom da očevi u našem radu nisu bili uključeni u analizu, njihova uloga i doprinos roditeljskoj saradnji, porodičnom funkcionisanju, a pre svega adekvatnom psihofizičkom rastu i razvoju deteta ostaje nam kao otvoreno pitanje za dalje analize.

\section{Reference}

Abidin, R.R., \& Brunner, J.F. (1995). Development of a parenting alliance inventory. Journal of Clinical Child Psychology, 24, 31-40.

Ackerman, N. (1966). Psihodinamika porodičnog života. Beograd: Prosveta

Ahrons, C.R. (1981). The continuing coparental relationship between divorced spouses. American Journal of Orthopychiatry, 51, 415-428.

Amato, P.R., \& Keith, B. (1991a). Parental divorce and well-being of children: A metaanalysis, Psychological Bulletin, 110(1), 26-46.

Belsky, J. (1984). The determinants of parenting, A process model. Child Development, 55, 83.96

Belsky, J., Crnic, K., \& Gables, S. (1995) The determinants of coparenting in families with todler boys. Spousal differences and daily hassles. Child Development, 66, 629-642. 
Block, J. H., Block, J., \& Morrison, A. (1981). Parental agreementdisagreement on child-rearing orientations and gender-related personality correlates in children. Child Development, 52, 965-974.

Bowlby, J. (1969). Attachment and loss: Vol 1 Attachment. NewYork: Basic Books.

Bronfenbrener, J. (1997). Ekologija ljudskog razvoja. Beograd: Zavod za udžbenike i nastavna sredstva.

Camara, K.A., \& Resnick, G. (1989). Styles of conflict resolution and cooperation between divorced parents: Effects on child behavior and adjustment. American Journal of Orthopsychiatry, 59, 560-575.

Fajgelj, S. (2005). Metode istraživanja ponašanja. Beograd: Centar za primenjenu psihologiju.

Feinberg, M. E. (2003). The internal structure and ecological context of coparenting: A framework for research and intervention. Parenting: Science and Practice, 3, 95-131.

Floyd, F.J., Gilliom, L.A., \& Costigan, C.L. (1998). Marriage and the parenting alliance: Longitudinal prediction of change in parenting perceptions and behaviors. Child Development, 69, 1461-1479.

Framo, J. L. (1992). Family inetractions. Philadelphia, Pennsylvania: Psychiatric Institute.

Gable, S., Belsky, J., \& Crnic, K. (1995). Coparenting during the child's 2nd year: A descriptive account. Journal of Marriage and the Family, 57, 609616.

Hendrickson, A., \& White, P.O. (1964). Promax: A quick method for rotation to oblique simple structure. British Journal of Statistical Psychology, 17, 65-70.

Hetherington, E.M., Cox, M., \& Cox, R. (1982). Effects of divorce on parents and children. In Lamb, M.E. (Ed.), Non-Traditional Families: Parenting and Child Development (pp. 223-228). Hillsdale, NY, Erlbaum.

Hotelling, H. (1933). Analysis of a complex of statistical variables into principal components. Journal of Educational Psychology, 24, 417-441, 495-520.

Hops, H., Sherman, L., \& Biglan, A. (1990). Maternal depression, marital discord, and children's behavior: A developmental perspective. In G. R. Patterson (Ed.), Depression and aggression in family interaction (pp. 185208). Hillsdale, NJ: Erlbaum. 
Huntley, D., \& Phelps, R. E. (1990). Depression and social contacts of children from one-parent families. Journal of Community Psychology 18, 66-78.

Kaiser, H.F. (1961). A note on Guttman's lower bound for the number of common factors. British Journal of Statistical Psychology, 14, 1-2.

Kapor-Stanulović, N. (1985.) Psihologija roditeljstva. Beograd: Nolit

Kennedy, J.H., \& Kennedy, C.E. (2004). Attachment theory: Implications for school psychology. Psychology in the schools, 41, 247-259.

Kuburić, Z. (1999) Porodica i psihičko zdravlje dece. Beograd: Čigoja.

Kvrgić, S. (2006). Procena zdravlja i kvaliteta života kod školske dece i omladine bez roditeljskog staranja. Nepublikovana doktorska disertacija. Univerzitet u Novom Sadu, Medicinski fakultet.

Landgraf, M.A., Abetz, L., \& Ware, J.E. (1996). The CHQ user's manual. Boston (MA): The Health Institute, New England, Medical Center.

Margolin, G., Gordis, E. B., \& John, R. S. (2001). Coparenting: A link between marital conflict and parenting in two-parent families. Journal of Family Psychology, 15, 3-21.

McBride, B. A., \& Rane, T. R. (1998). Parenting alliance as a predictor of father involvement: An exploratory study. Family Relations, 47, 229-236.

Mihić, I. (2007). Koroditeljski odnosi - prikaz dva instrumenta za procenu kvaliteta koroditeljske saradnje U Biro,M., i Smederevac, S. (Ur.), Psihologija i društvo (pp. 163 - 177). Novi Sad: Filozofski fakultet u Novom Sadu, Odsek za psihologiju:

Minuchin, P. (1985). Families and individual development: Provocations from the field of family therapy. Child Development, 56, 289-302.

Mitić, M. (1992) Porodica i promene. Psihološka istraživanja, 5, Beograd: Institut za psihološka istraživanja, 49-62

Nićiforović - Šurković, O. (2000) Vrednovanje zdravlja kod školske dece i njihovih roditelja - navike vezane za zdravlje. Nepublikovana magistarska teza. Univerzitet u Novom Sadu, Medicinski fakultet, Novi Sad.

Piorkowska-Petrović, K. (1994) Roditeljske uloge i socijalni razvoj deteta. Zbornik instituta za pedagoška istraživanja, 26, 111- 131.

Weissman, S., \& Cohen, R. (1985). The parenting alliance and adolescence. Annals of the American Society for Adolescent Psychiatry, 12, 24-45. 
Whiteside, M. F. (1998) The parental alliance following divorce: an overview. Journal of Marital an Family Therapy, 1, 3-24.

Zotović, M. (2004). Stres i mentalno zdravlje dece. Beograd: Zadužbina Andrejević.

Žlebnik, L. (1972). O razvoju deteta i mladih uopšte. U: Psihologija deteta i mladih 1.Beograd, Delta-Press, 94- 13. 


\section{Abstract \\ PARENTING ALLIANCE AND ITS RELATIONS TO COMPONENTS OF PSYCHOPHYSICAL WELL-BEING OF CHILDREN}

Đerđi Erdeš - Kavečan

In the research literature parenting alliance is a conceptual term that refers to the ways that parents relate to each other in the role of parent. Coparenting occurs when individuals have overlapping or shared responsability for rearing particular children, and consists of the support and coordination (or lack of it) that parental figures exhibit in childrearing.The coparenting relationship does not include the romantic, sexual, companionate, emotional, financial and legal aspects of the adults's relationship that do not relate to childrearing. Furthermore, the term coparenting does not imply that parenting roles are or should be equal in authority or responsibility.

The research presented in this paper had the aim to examine relations between parenting alliance and the components of psychophysical well-being of preschool and school age children.

The research was conducted on sample of 248 mothers from Novi Sad. Instruments with which we collected data were as follows: Parenting Alliance Measure Scale (Abidin, Konold, 1999) and Child Health Questionnaire - for the purposes of research composed of 40 items from the original CHQ / Child Health Questionnaire (Landgraf, Ware Jr., 1996).

By analyzing the latent structure of this reserach, we aquired data, which showed us, that parenting alliance is correlated with five dimensions of psychosocial and with one dimension of physical well-being of a child. These data suggest a significance of parental cooperation and generally the significance of family relations in the impact of emotional, social and physical functioning of the child. However, the causes of negative psychophysical functioning is very hard to discover. Therefore, more precise informations would be obtaind by rersearching some personal characteristics of parents and children, as well as researching the context of parenting.

Key words: parenting alliance, psychophysical well-being, relations, psychometric properties

Primljeno: 22. 6. 2009; prihvaćeno za štampu: 21. 9. 2009. 302 